\title{
Experimental models of polycystic ovary syndrome
}

\section{Polikistik over sendromu oluşturmak için kullanılan deneysel modeler}

\author{
Mehmet ÇINAR, Özlem GÜN ERYILMAZ
}

\begin{abstract}
Polycystic ovary syndrome (PCOS) is the most common endocrine metabolic disorder in women. Although many animal and human studies have been conducted, mechanisms involved in polycystic ovary formation and related metabolic dysfunction have not been fully understood,. Different techniques have been tried on animals to induce PCOS. Chronologically, the experimental methods used to induce PCOS included dehydroepiandrosterone application, estradiol valerate injection, fetal androgen administration, antiprogesterone (RU486) application and letrozole use. All of these models were described in this review article.
\end{abstract}

öz

Polikistik over sendromu (PKOS), kadınlarda en sık görülen metabolic bozukluktur. Oluşum mekanizması halen net olarak aydınlanmamış olan PKOS ile alakalı pek çok hayvan çalışmaları mevcuttur. PKOS modeli oluşturmak ve hastalık mekanizmasını anlamak amacıyla, sırasıyla dehidroepiandrosteron sülfat uygulaması, östradiol valerate enjeksiyonu, fetal androgen verilmesi, antiprogestin (RU486) uygulanması ve letrozol uygulaması denenmiştir. Derlememizde, bu modelleri derlemeye çalıştık.

\section{INTRODUCTION}

Polycystic ovary syndrome (PCOS), is the most common endocrine metabolic disorder in women of reproductive age with a prevalence of 5-20\% ${ }^{1,2}$. Diagnostic criteria for PCOS have been revised in 2003 and new guidelines were issued by the Rotterdam Workshop Group ${ }^{3}$. According to these guidelines, two out of three of the following should be met to make a of PCOS:

a. Hyperandrogenism, as determined by elevated circulating levels of total or free testosterone or clinical signs of hirsutism.

b. Intermittent or absent menstrual cycles.

c. Polycystic ovaries (as visualized on ultrasonograms).

Reproductive and endocrine disturbances seen in PCOS include hypersecretion of $\mathrm{LH}$, adrenal hyperandrogenism, ovarian hyper-responsiveness to go- nadotropin in intrauterine insemination and in vitro fertilization, and endometrial hyperplasia with possible progression to endometrial cancer. Increased miscarriage rates, presumably linked to the genetic dysregulation in oocytes and endometrial cells have been also reported in cases with infertility ${ }^{4}$. Obesity and insulin resistance are frequently seen among PCOS patients with a prevalence of $30 \%$ and $60-75 \%$, respectively ${ }^{5}$. Compensatory hyperinsulinemia, impaired glucose tolerance and type 2 diabetes mellitus are common metabolic manifestations, accompanying obesity in PCOS patients ${ }^{6,7}$. Hyperlipidemia together with impaired glucose tolerance contributes to endothelial dysfunction that leads to atherosclerotic vascular changes and myocardial dysfunction, both of which increase the risk for cardiovascular disease in later years ${ }^{8-10}$.

PCOS has a multi-system presentation. The mecha-

Received: 23.12 .2015

Accepted: 13.01 .2016

Zekai Tahir Burak Women's Health Education and Research Hospital, Department of Reproductive Endocrinology and Infertility

Yazışma adresi: Mehmet Çınar, Zekai Tahir Burak Women's Health Education and Research Hospital, Department of Reproductive Endocrinology and Infertility, Ankara

e-mail: drmcinar@gmail.com 
nisms involved in polycystic ovary formation and related metabolic dysfunction have not been fully understood, although many animal and human studies have been conducted. Different techniques were experimented on animals to induce PCOS. Initially, dehydroepiandrosterone (DHEA) was used to instigate PCOS in animal models ${ }^{11,12}$. This was followed by estradiol valerate injection ${ }^{13}$, fetal androgen application $^{14}$ and letrozole administration. Whether PCOS has an in utero etiology or is due to a hormonal disturbance occurring in adolescence or later, has been extensively studied. All of the attempts mentioned above have led to the appearance of PCOS in animals, as evidenced by the classical polycystic morphology of ovaries and most of the hormonal imbalances characteristic of PCOS.

In this review article we aimed to summarize these experiments and their models related to PCOS. These models are;

\section{Hormonal methods to induce PCOS}

\section{a) Dehydroepiandrosterone applications}

As early as in the 1960s, DHEA application was the first procedure used to induce polycystic ovaries in animals. It was administered to normally cyclic rats that subsequently developed anovulation and cystic degenerations in their ovaries. Roy et al. ${ }^{11}$ demonstrated ovulation failure and formation of polycystic ovaries following administration of DHEA. The experimental dosage of DHEA ranged from $1.5 \mathrm{mg} / \mathrm{kg}$ to 6 $\mathrm{mg} / \mathrm{kg}$ body weight via subcutaneous injections. Experiments with all of the different doses $(1.5 \mathrm{mg} / \mathrm{kg}$; $3 \mathrm{mg} / \mathrm{kg} ; 4 \mathrm{mg} / \mathrm{kg}$ or $6 \mathrm{mg} / \mathrm{kg}$ ) have led to the typical ovarian appearance of PCOS. Ten or 20 days of DHEA application was equally effective as assessed by the pattern of cystic and degenerative follicles on histological exams.

Upon administration of DHEA, FSH and prolactin levels were shown to be increased, while LH levels were decreased. These changes were similar with both $3 \mathrm{mg} / \mathrm{kg}$ or $6 \mathrm{mg} / \mathrm{kg}$ doses. Different duration of DHEA administration (3, 7, 11 and 15 days) have led to similar outcomes in terms of gonadotropin levels. Increased prolactin concentrations following DHEA administration might be the result of increased estrogen production due to conversion of DHEA to estrogen in the ovaries ${ }^{15}$.

\section{b) Estradiol valerate applications}

Administration of estradiol valerate (EV) to prepubertal rats was shown to disrupt the ovarian cycle via activation of the sympathetic ovarian nerve and increased intra-ovarian expression of norepinephrine (NE). Rosa-E-Silva et al. administered a single intramuscular injection of $2 \mathrm{mg}$ of EV in $0.2 \mathrm{ml}$ of corn oil into the study group of rats via subcutaneous injections. They tried to investigate the effect of prepubertal EV administration by observing for resultant anovulatory state and/or cystic morphologic changes in the ovaries following administration. In the ovaries, EV induced the secretion of thyrosine kinase, which is the rate-limiting enzyme in NE synthesis ${ }^{16}$. The subsequent increase in NE interrupted the ovarian cycle and led to ovulatory dysfunction. After sympathetic denervation of the ovaries, they evaluated the impact of decreased levels of intraovarian norepinephrine on prevention of PCOS. They concluded that prepubertal presence of EV in a rat ovary resulted in early pubertal onset, activation of the sympathetic ovarian nerve, and increased NE synthesis and induced formation of an anovulatory state with cystic ovarian morphology. Inhibition of NE release by sympathetic nerve denervation prevented ovarian transformation typical of PCOS, despite administration of $\mathrm{EV}^{17}$. Administration of EV suppressed circulating LH, FSH and $\Delta 4$ androstenedione levels and increased ovarian norepinephrine and estradiol concentrations. The action of LH was not as significant as that observed in the clinical presentation of PCOS patients. However, increased levels of intraovarian NE were shown to be responsible for cystic ovarian changes.

\section{c) Fetal androgen application}

Early embryonic stage is a critical stage of develop- 
ment. Any chemical stimulus or injury at this stage may easily affect the ongoing developmental process and carry a life-long impact. An imbalance in androgen concentration at this early embryonic stage was associated with polycystic ovarian formation ${ }^{18}$. Widdowson et al. ${ }^{19}$ concluded that excess androgen disturbed reproductive functioning by its action on the hypothalamic-pituitary-gonadal axis. Increased androgen administration to pregnant animals induced characteristic PCOS changes, indicated by ovarian morphology and clinical symptoms ${ }^{20,21}$. Abbott et al. ${ }^{22}$ demonstrated that female rhesus monkeys with in utero exposure to androgen levels equivalent to those seen naturally in their male counterparts, expressed clinical signs distinctive of PCOS. Wu et al. ${ }^{23}$ confirmed the relationship of in utero androgen introduction and cystic ovarian formation in rats. The two rat groups of this study were given $3 \mathrm{mg}$ testosterone $(\mathrm{T})$ and $3 \mathrm{mg}$ dihydrotestosterone (DHT) every day from 16. to 19. days of gestation via subcutaneous injections. Histological examination revealed an increased number of preantral follicles in the study group exposed to T and DHT. Biochemical analysis of the gonadotropins showed increased T and DHT levels. This hyperandrogenic state was similar to that seen in PCOS patients. The experimental group showed increased LH levels, consistent with the hormonal imbalance seen in PCOS patients. Anti-estrogenic effect of the androgens led to decreased E2 levels and the negative feedback of E2 on the hypothalamic receptors was interrupted. This resulted in increased concentrations of LH. Impaired periodicity in response to gonadotropin stimulation and the release of androgens contributed to menstrual dysfunction (oligomenorrhoea and/or amenorrhea), similar to the clinical presentation of PCOS. The researchers concluded that PCOS is a complex disease and excess androgen is only one factor relevant to the mechanism of PCOS pathogenesis.

\section{d) Letrozole administration}

In another experimental model of PCOS an aromatase inhibitor letrozole was used. Manneras et al. ${ }^{24}$ worked on an animal model of PCOS in order to eva- luate the morphological changes in the ovary and the ensuing metabolic states. Their research focused on adiposity as an etiological factor in the development of PCOS and the resulting metabolic disturbances of animal subjects. They subcutaneously implanted 90 day continuous-release pellets of dihydrotestosterone (DHT, $7.5 \mathrm{mg}$, daily dose $83 \mathrm{~g}$ ) and letrozole (36 $\mathrm{mg}$, daily dose $400 \mathrm{~g}$ ) separately in animals belonging to two different study groups and assessed ovarian morphology, histology, body weight, body fat, mesenteric adiposities and insulin resistance. Menstrual periodicity was disturbed in both study groups. Letrozole administered rats were completely acyclic, while DHT application produced irregular cycles. Morphologic features of the ovaries were similar to those seen in human patients. The number of cystic follicles increased in response to DHT and letrozole when compared with the control group. Atresia of antral follicles and follicular cysts were also dominant in DHT and letrozole implanted rats. The cysts in these rats were located in the periphery of the ovary, similar to the orientation of cysts in PCOS patients. As expected, testosterone levels were increased in rats given DHT and letrozole. E2 levels were unaltered and progesterone levels decreased. Body composition, analyzed by DEXA, was found to be increased upon DHT and letrozole application when compared to controls. Body fat distribution was increased only in the DHT group, while letrozole group was not different from the controls. Insulin sensitivity was found to be decreased in DHT administered rats but not in rats exposed to letrozole. DHT implanted rats showed an increase in the mean mesenteric adipocyte size, which was unaffected in rats that received letrozole. In conclusion, the letrozole model was useful for studies of the ovarian features of PCOS, while the DHT model was useful for studies of both ovarian and metabolic features of the syndrome.

\section{e) Antiprogestin RU486}

RU486 is a synthetic steroid that shows a high affinity for progesterone and glucocorticoid receptors. RU486 has potent antagonistic activity without agonistic activity for progesterone receptors ${ }^{25}$. Application of 
Table 1. The association between experimental PCOS models and human diagnostic traits of PCOS.

\begin{tabular}{|c|c|c|c|c|c|c|c|c|}
\hline $\begin{array}{l}\text { Experimental } \\
\text { PCOS models }\end{array}$ & Acyclicity & $\begin{array}{c}\text { Hyper } \\
\text { androgenism }\end{array}$ & $\begin{array}{c}\text { Oligo/ } \\
\text { anovulation }\end{array}$ & $\begin{array}{l}\text { Polycystic } \\
\text { ovaries }\end{array}$ & $\begin{array}{l}\text { 个Follicle } \\
\text { atresia }\end{array}$ & $\begin{array}{c}\text { LH } \\
\text { Hyper secretion }\end{array}$ & $\begin{array}{l}\text { Insuline } \\
\text { resistance }\end{array}$ & Obesity \\
\hline DHEA & + & + & + & + & + & + & + & - \\
\hline EV & + & - & + & + & + & - & - & + \\
\hline FAA & + & + & + & + & + & - & + & $?$ \\
\hline LA & + & + & + & + & + & + & + & + \\
\hline RU486 & + & + & + & + & + & + & - & - \\
\hline
\end{tabular}

DHES: Dehydroepiandrosterone, EV: estradiol valerate, FAA: fetal androgen application, LA: letrozole administration

RU486 in rats eliminates progesterone activity and creates many endocrine and ovarian morphological features similar to human PCOS. Treatment of RU486 with adult cycling female rats for 4-9 days resulted in acyclicity, polycystic ovaries, and anovulation ${ }^{26,27}$. Changes in ovaries include increased number of atretic follicles ${ }^{28}$ and thin granulosa cell layers ${ }^{29}$. Similar to human PCOS, serum LH, T, and E2 levels were increased $^{29}$. FSH levels were variable, with different models displaying unchanged, increased, or decreased FSH levels. With regard to metabolic abnormalities related to human PCOS, RU486 application does not cause any change body weight or insulin sensitivity ${ }^{30}$. As a result, rats treated with subcutaneously implanted RU486 shows many features found in women with PCOS, including acyclicity, anovulation, presence of follicular cysts and elevated androgen and LH levels.

\section{CONCLUSION}

Experimental models for induction of PCOS are important in understanding the mechanisms underlying its physiopathology. Table 1 summarized the association between experimental PCOS models and human diagnostic traits of PCOS. Hormonal imbalance during prenatal or postnatal periods may trigger the syndrome. Intraovarian sympathetic nerve stimulation via NE may alter the microenvironment and disturb folliculogenesis. Adiposity may be a cofactor involved in the transformation of a functional ovary into a dysfunctional, cystic one. Despite many experimental studies on PCOS, the exact mechanism is not yet elucidated. Since it is a multifaceted disease and affects various systems, further animal and human studies should be performed.

\section{REFERENCES}

1. Franks S. Polycystic ovary syndrome. $N$ Engl J Med 1995;333:853-61. http://dx.doi.org/10.1056/NEJM199509283331307

2. Fenton A, Panay N. Management of polycystic ovary syndrome in postmenopausal women: a medical black hole. Climacteric 2008;11:89-90.

http://dx.doi.org/10.1080/13697130801972304

3. Revised 2003 consensus on diagnostic criteria and long-term health risks related to polycystic ovary syndrome. Fertil Steril 2004;81:19-25.

http://dx.doi.org/10.1016/j.fertnstert.2003.10.004

4. Wang JX, Davies MJ, Norman RJ. Polycystic ovarian syndrome and the risk of spontaneous abortion following assisted reproductive technology treatment. Hum Reprod 2001;16:2606-9.

http://dx.doi.org/10.1093/humrep/16.12.2606

5. Calle EE, Kaaks R. Overweight, obesity and cancer: epidemiological evidence and proposed mechanisms. Nat Rev Cancer 2004;4:579-91.

http://dx.doi.org/10.1038/nrc1408

6. Katsiki N, Hatzitolios Al. Insulin-sensitizing agents in the treatment of polycystic ovary syndrome: an update. Curr Opin Obstet Gynecol 2010;22:466-76.

http://dx.doi.org/10.1097/GCO.0b013e32833e1264

7. Gottschau M, Kjaer SK, Jensen A, et al. Risk of cancer among women with polycystic ovary syndrome: a Danish cohort study. Gynecol Oncol 2015;136:99-103.

http://dx.doi.org/10.1016/j.ygyno.2014.11.012

8. Ehrmann DA, Liljenquist DR, Kasza K, et al. Prevalence and predictors of the metabolic syndrome in women with polycystic ovary syndrome. J Clin Endocrinol Metab 2006;91:48-53. http://dx.doi.org/10.1210/jc.2005-1329

9. Dilbaz B, Ozkaya E, Cinar M, et al. Cardiovascular disease risk characteristics of the main polycystic ovary syndrome phenotypes. Endocrine 2011;39:272-7. http://dx.doi.org/10.1007/s12020-011-9437-6

10. Daskalopoulos GN, Karkanaki A, Karagiannis A, et al. Is the risk for cardiovascular disease increased in all phenotypes of the polycystic ovary syndrome? Angiology 2011;62:285-90. http://dx.doi.org/10.1177/0003319711399571

11. Roy S, Mahesh VB, Greenblatt RB. Effect of dehydroepiandrosterone and delta4-androstenedione on the reproductive organs of female rats: production of cystic changes in the ovary. Nature 1962;196:42-3. http://dx.doi.org/10.1038/196042a0

12. Motta AB. Dehydroepiandrosterone to induce murine models for the study of polycystic ovary syndrome. J Steroid Bi- 
ochem Mol Biol 2010;119:105-11. http://dx.doi.org/10.1016/j.jsbmb.2010.02.015

13. Lara HE, Ferruz JL, Luza S, et al. Activation of ovarian sympathetic nerves in polycystic ovary syndrome. Endocrinology 1993;133:2690-5.

14. Merke DP, Cutler GB, Jr. New ideas for medical treatment of congenital adrenal hyperplasia. Endocrinol Metab Clin North Am 2001;30:121-35. http://dx.doi.org/10.1016/S0889-8529(08)70022-7

15. Fink G. Oestrogen and progesterone interactions in the control of gonadotrophin and prolactin secretion. J Steroid Biochem 1988;30:169-78. http://dx.doi.org/10.1016/0022-4731(88)90090-8

16. Maliqueo M, Benrick A, Stener-Victorin E. Rodent models of polycystic ovary syndrome: phenotypic presentation, pathophysiology, and the effects of different interventions. Semin Reprod Med 2014;32:183-93. http://dx.doi.org/10.1055/s-0034-1371090

17. Masszi G, Horvath EM, Tarszabo R, et al. Reduced estradiolinduced vasodilation and poly-(ADP-ribose) polymerase (PARP) activity in the aortas of rats with experimental polycystic ovary syndrome (PCOS). PLoS One 2013;8:e55589. http://dx.doi.org/10.1371/journal.pone.0055589

18. Yu H, Bian XM, Liu JT, et al. Pregnancy outcomes of eight pregnant women with congenital adrenal hyperplasia due to 21-hydroxylase deficiency. Zhonghua Fu Chan Ke Za Zhi 2012;47:651-4.

19. Widdowson EM, McCance RA. A review: new thoughts on growth. Pediatr Res 1975;9:154-6. http://dx.doi.org/10.1203/00006450-197503000-00010

20. Blank SK, McCartney CR, Marshall JC. The origins and sequelae of abnormal neuroendocrine function in polycystic ovary syndrome. Hum Reprod Update 2006;12:351-61. http://dx.doi.org/10.1093/humupd/dml017

21. Foecking EM, McDevitt MA, Acosta-Martinez M, et al. Neuroendocrine consequences of androgen excess in female rodents. Horm Behav 2008;53:673-92. http://dx.doi.org/10.1016/j.yhbeh.2007.12.013

22. Abbott DH, Dumesic DA, Eisner JR, et al. Insights into the de- velopment of polycystic ovary syndrome (PCOS) from studies of prenatally androgenized female rhesus monkeys. Trends Endocrinol Metab 1998;9:62-7. http://dx.doi.org/10.1016/S1043-2760(98)00019-8

23. Wu XY, Li ZL, Wu CY, et al. Endocrine traits of polycystic ovary syndrome in prenatally androgenized female SpragueDawley rats. Endocr J 2010;57:201-9.

http://dx.doi.org/10.1507/endocrj.K09E-205

24. Caldwell AS, Middleton LJ, Jimenez $M$, et al. Characterization of reproductive, metabolic, and endocrine features of polycystic ovary syndrome in female hyperandrogenic mouse models. Endocrinology 2014;155:3146-59. http://dx.doi.org/10.1210/en.2014-1196

25. Baulieu EE. The antisteroid RU486: its cellular and molecular mode of action. Trends Endocrinol Metab 1991;2:233-9. http://dx.doi.org/10.1016/1043-2760(91)90030-Q

26. Zhou H, Ohno N, Terada N, et al. Involvement of follicular basement membrane and vascular endothelium in blood follicle barrier formation of mice revealed by 'in vivo cryotechnique'. Reproduction 2007;134:307-17. http://dx.doi.org/10.1530/REP-07-0062

27. Ruiz A, Aguilar R, Tebar AM, et al. RU486-treated rats show endocrine and morphological responses to therapies analogous to responses of women with polycystic ovary syndrome treated with similar therapies. Biol Reprod 1996;55:1284-91. http://dx.doi.org/10.1095/biolreprod55.6.1284

28. Tebar M, Ruiz A, Bellido C, et al. Ovary mediates the effects of RU486 given during proestrus on the diestrous secretion of luteinizing hormone in the rat. Biol Reprod 1996;54:1266-70. http://dx.doi.org/10.1095/biolreprod54.6.1266

29. Yung Y, Maman E, Ophir L, et al. Progesterone antagonist, RU486, represses LHCGR expression and LH/hCG signaling in cultured luteinized human mural granulosa cells. Gynecol Endocrinol 2014;30:42-7. http://dx.doi.org/10.3109/09513590.2013.848426

30. Lakhani K, Yang W, Dooley A, et al. Aortic function is compromised in a rat model of polycystic ovary syndrome. Hum Reprod 2006;21:651-6. http://dx.doi.org/10.1093/humrep/dei399 